\section{Application of Floating Culture System on Clonal Propagation of Taiwanese Wild Grape}

\author{
Szu-Chin Peng, Iou-Zen Chen, and Cheng-Yung Cheng ${ }^{1}$
}

AdDitional INDEX WORDs. Vitis thunbergii, softwood cuttings, rooting, circulating water, propagation medium temperature

Summary. In this study, we built a floating culture system, which could improve the rooting percentage of stem cuttings of taiwanese wild grape (Vitis thunbergii). We took softwood cuttings instead of hardwood cuttings and tested the effects of cutting type, medium type, and auxin concentration on the rooting percentage. In the first experiment, single leaf cuttings (SLC) in $26^{\circ} \mathrm{C}$ circulating water $\left(\mathrm{CW}_{26}\right)$ produced $82 \%$ rooting as compared with $48 \%$ rooting in the subirrigation medium [SM (3 horticultural perlite : 2 peatmoss, by volume)]. The highest rooting percentage of $88 \%$ occurred in $30^{\circ} \mathrm{C}$ circulating water $\left(\mathrm{CW}_{30}\right)$. The same trend was also observed in terminal cuttings (TC) with $62 \%$ rooting in $\mathrm{CW}_{26}$ compared with $27 \%$ in SM. The highest rooting percentage of $83 \%$ occurred in $\mathrm{CW}_{30}$. Besides having the highest rooting percentage, TC and SLC in $\mathrm{CW}_{30}$ formed adventitious roots 7 and $9 \mathrm{~d}$ earlier than in $22{ }^{\circ} \mathrm{C}$ circulating water $\left(\mathrm{CW}_{22}\right)$. In the second experiment, SLC in $1.25 \mu \mathrm{M}$-naphthalenacetic acid (NAA) solution produced $92 \%$ rooting as compared with $82 \%$ rooting in the untreated group. In addition, SLC in all NAA solution treatments formed adventitious root $6 \mathrm{~d}$ earlier than in the untreated group. Based on these results, we suggest that the floating culture system is a practicable system for the clonal propagation of taiwanese wild grape.

$\mathrm{T}$ aiwanese wild grape is a perennial herb that is traditionally used in medical therapy in eastern Asia. Recently, growers tried to cultivate taiwanese wild grape artificially, but they had some problems such as low rooting percentage in clonal propagation. In a preliminary study in 2003, we examined the rooting percentage of clonal hardwood cuttings of taiwanese wild grape using conventional materials. However, the rooting percentage of taiwanese wild grape hardwood cutting was too low to be useful for mass propagation. It was reported that taiwanese wild grape could be clonal propagated through high-frequency shoot tip culture (Lu, 2005). However, the proliferation system takes lots of labor and time. Some reports mentioned that softwood cuttings could be used for clonal propagation of norton grapes (Vitis aestivalis) and muscadine grapes (Vitis rotundifolia) (Goode and Lane, 1983; Keeley et al., 2003). So we tried to take softwood cuttings instead of hardwood cuttings for clonal propagation.

Department of Horticulture, National Taiwan University, No. 1, Sec. 4, Roosevelt Road, 10617 Taipei, Taiwan, Republic of China

We thank Ming-Wen Chang for acquiring taiwanese wild grape plantings.

${ }^{1}$ Corresponding author. E-mail: cheng@ntu.edu.tw.
For softwood cuttings, many researchers have focused on the atmospheric environment of the propagation area to promote rooting percentage. Since the 1950 s, overhead intermittent mist irrigation has been the conventional means of maintaining the water potential of cuttings and it has increased the rooting percentage in many plant species (LeBude et al., 2004; Mudge et al., 1995). Subirrigation is another common system used to reduce water stress for successful rooting of cuttings (Owen et al., 2003; Post, 1946; Zhang et al., 1997). However, these two systems are costly in terms of equipment. Therefore, we built a floating culture system (Fig. 1) for clonal propagation of taiwanese wild grape.

The objective of this study was to examine the effects of cutting type, medium type, and auxin concentration on the rooting percentage of taiwanese wild grape in a floating culture system.

\section{Materials and methods}

Plant materials. Ten clonally propagated vines of taiwanese wild grape (4 years old) were cultivated in the vineyard of the department of horticulture at National Taiwan University (Taipei, Taiwan). Softwood cuttings were collected on 11 July (for the first experiment) and 10 Aug. (for the second experiment) in 2005. After collection, each cutting was immediately inserted into water. Cuttings were transported to the laboratory on the collection day and were divided into two cutting types as follows: 1) terminal cuttings, terminal bud with four young leaves and five nodes ( $\approx 10$ to $12 \mathrm{~cm}$ in length); or 2) single leaf cuttings, latent axillary bud with one mature leaf, and one node (the sixth to 10th node from the terminal bud, $\approx 5$ to $7 \mathrm{~cm}$ in length).

EXPERIMENTAL CONDITIONS. Experiments were conducted in a controlled-environment growth chamber in the laboratory. The chamber setting was $25{ }^{\circ} \mathrm{C}$ day $/ 20{ }^{\circ} \mathrm{C}$ night and $90 \%$ relative humidity. Light (average $600 \mu \mathrm{mol} \cdot \mathrm{m}^{-2} \cdot \mathrm{s}^{-1}$ ) was applied by fluorescent lamps 20 to $25 \mathrm{~cm}$ above the propagation canopy $16 \mathrm{~h}$ each day. The floating culture system (Fig. 1) was composed of a water bath circulator (B206-T2; Firsteck Scientific, Taipei, Taiwan) and floating microtube racks (MFl6; Bioman Scientific, Taipei, Taiwan). The initial water volume of each system was $12 \mathrm{~L}$. Cuttings were put into the holes of floating racks and inserted at a depth of $\approx 4 \mathrm{~cm}$ in distilled water. Distilled water was added, as needed, directly into the tank to maintain the water volume.

MEDium TREATMENTS AND EXPERIMENTAL DESIGN. In the first experiment, four different media were examined: 1) subirrigation medium, which was a mixture of 3 perlite : 2 peatmoss (by volume); 2) $22{ }^{\circ} \mathrm{C}$ circulating distilled water; 3$) 26^{\circ} \mathrm{C}$ circulating distilled water; or 4$) 30^{\circ} \mathrm{C}$ circulating distilled water. The water

\begin{tabular}{llll}
\hline $\begin{array}{l}\text { Units } \\
\begin{array}{l}\text { To convert U.S. to SI, } \\
\text { multiply by }\end{array}\end{array}$ & U.S unit & SI unit & $\begin{array}{l}\text { To convert SI to U.S., } \\
\text { multiply by }\end{array}$ \\
\hline 3.7854 & gal & $\mathrm{L}$ & 0.2642 \\
2.54 & inch $(\mathrm{es})$ & $\mathrm{cm}$ & 0.3937 \\
25.4 & inch $(\mathrm{es})$ & $\mathrm{mm}$ & 0.0394 \\
$\left({ }^{\circ} \mathrm{F}-32\right) \div 1.8$ & ${ }^{\circ} \mathrm{F}$ & ${ }^{\circ} \mathrm{C}$ & $\left(1.8 \times{ }^{\circ} \mathrm{C}\right)+32$
\end{tabular}

hathediogy $\cdot$ July-September 2008 18(3) 


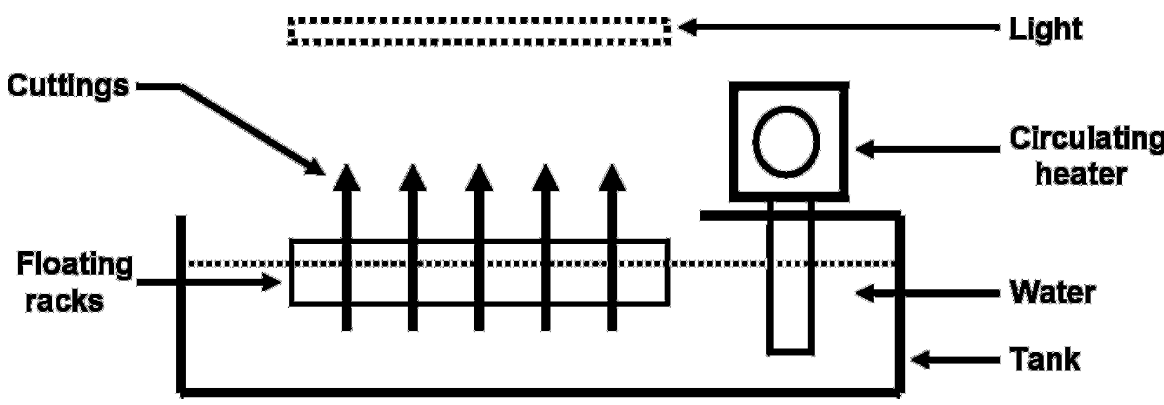

Fig. 1. Diagram of the floating culture system used for clonal propagation of taiwanese wild grape. It was composed of a water bath circulator and floating microtube racks. Cuttings were put into the holes of floating racks and inserted in the distilled water. Light (average $600 \mu \mathrm{mol} \cdot \mathrm{m}^{-2} \cdot \mathrm{s}^{-1}$ ) was applied by fluorescent lamps $20 \mathrm{~cm}$ ( 7.9 inches) above propagation canopy $16 \mathrm{~h}$ each day.

media were circulated and heated by water bath circulators. The subirrigation medium $(\mathrm{SM})$ was filled in plastic baskets $(40 \mathrm{~cm}$ long, $25 \mathrm{~cm}$ wide, $5 \mathrm{~cm}$ high) with drain holes toward the bottom. To maintain the water potential of SM, all baskets were set in plastic trays $(45 \mathrm{~cm}$ long, $30 \mathrm{~cm}$ wide, $1 \mathrm{~cm}$ high) with $1-\mathrm{cm}$ deep distilled water. Water checking was done twice each day to make sure that the water level of SM was maintained at $1 \mathrm{~cm}$ deep. The temperature of SM was measured as $26 \pm 1{ }^{\circ} \mathrm{C}$. We measured the rooting percentage, root number, and the total length of roots 3 weeks after cutting. A cutting was considered rooted if it had at least one root greater than $2 \mathrm{~mm}$ in length. To compare the adventitious root formation rate of cuttings in different media, we recorded the rooting percentage of cuttings in circulating water $(\mathrm{CW})$ everyday (to avoid hurting the roots of cuttings in SM, we only observed them at the end of this experiment) and calculated the day on which $50 \%$ rooting of cuttings were rooted $\left(R_{50}\right)$.

In the second experiment, 1naphthalenacetic acid (NAA) was added to the $\mathrm{CW}_{26}$ at the following rates: $1.25,2.5$, and $5 \mu \mathrm{M}$ NAA solutions held at $26^{\circ} \mathrm{C}$ were applied as rooting media. $\mathrm{CW}_{26}$ was used as a control. We recorded the rooting percentage everyday and calculated the day on which $R_{50}$ occurred. This experiment was conducted for 3 weeks.

A completely randomized design was used for both experiments. One hundred cuttings $[50$ terminal cuttings (TC) and 50 single leaf cuttings (SLC)] were used per floating culture system. Each treatment involved three replications for a total of 12 floating culture systems used per experiment.

Statistical ANALYsis. The mean values, SDs, and statistical differences were evaluated through an analysis of variance that was performed with SAS (v8; SAS Institute, Cary, NC). The main effects of the cutting type, the medium type, and the two-way interaction were tested for all rooting traits assessed. To homogenize the variances between different treatments, the variables of rooting percentage were transformed by using the arcsine of the square root.

\section{Results and discussion}

In SM, SLC had $48 \%$ rooting compared with $27 \%$ for TC. The same trend was also observed in circulating water media such as $\mathrm{CW}_{22}$ and $\mathrm{CW}_{26}$ media with SLC having a higher rooting percentage than TC. However, there was no difference in rooting percentage between SLC and TC in $\mathrm{CW}_{30}$ medium (Table 1 ). For softwood cuttings, wilting and rot are lethal factors in the first few days after being cut from the vines. SLC are more mature and usually have more lignified tissues than TC and can maintain tissue water potential more constantly and have greater chances to form adventitious root (Goode and Lane, 1983). We assume that $\mathrm{TC}$ in $\mathrm{CW}_{30}$ treatment formed adventitious roots earlier and thus the wilting possibility was dramatically reduced. Therefore, the rooting percentage of TC in $\mathrm{CW}_{30}$ increased and showed no statistical difference from SLC.
Cuttings in circulating water rooted significantly better than in SM and the rooting percentage was greatest in the $\mathrm{CW}_{30}$ medium than in $\mathrm{CW}_{26}$ or $\mathrm{CW}_{22}$ media (Table $\mathrm{l}$ ). This may be because cuttings in water can maintain tissue water potential more constantly than in SM and have greater chances to form adventitious root. Mixtures of sand or perlite with peatmoss are widely used as rooting media for cuttings because these mixtures can hold water, which prevents the lower end of the stem from drying while remaining loose enough to allow oxygen to reach the newly forming roots (Sabir et al., 2004). Water is not thought to be a good medium to root most cuttings because an adequate amount of oxygen cannot reach developing roots (Soffer and Burger, 1988; Zimmerman, 1930). To increase the concentration of oxygen in water medium, bubbling was reported as an applicable method (Zimmerman, 1930). Water culture was suggested as a simple and efficient method for rooting some species' woody cuttings (Komissarov, 1968). In this study, circulating water was a suitable medium for rooting softwood cuttings of taiwanese wild grape

For TC, the $\mathrm{R}_{50}$ occurred on the 13th day after cutting in $\mathrm{CW}_{22}$. When we increased the medium temperature, the time required to reach $\mathrm{R}_{50}$ was antedated to the eighth day and sixth day in $\mathrm{CW}_{26}$ and $\mathrm{CW}_{30}$, respectively (Table 1 ). The same trend was also observed in SLC with $\mathrm{R}_{50}$ occurring $9 \mathrm{~d}$ earlier because of heating the circulating water to $30^{\circ} \mathrm{C}$ rather than $22^{\circ} \mathrm{C}$ (Table 1$)$. In addition, the total length of roots of TC and SLC in $\mathrm{CW}_{30}$ were 19.7 and $13.9 \mathrm{~cm}$, respectively, as compared with 7.8 and 8.8 $\mathrm{cm}$ in $\mathrm{CW}_{26}$ (Table $\mathrm{l}$ ). We suspect that heating the medium temperature to $30{ }^{\circ} \mathrm{C}$ accelerated the metabolism rate as well as the adventitious root formation process.

Similar experiments were also reported in recirculating subirrigation systems used for softwood propagation of sparkleberry holly (Ilex verticillata) (Owen et al., 2003) and maple (Acer rubrum) cuttings (Zhang et al., 1997) with perlite medium. For sparkleberry holly, rooting percentage of cuttings increased from $38 \%$ to $80 \%$ while heating media from 20 to $23{ }^{\circ} \mathrm{C}$. This result 
Table 1. Traits assessed in the medium type experiment of softwood cuttings of taiwanese wild grape.

\begin{tabular}{|c|c|c|c|c|c|c|c|c|}
\hline \multirow[b]{2}{*}{ Medium type $^{\mathrm{z}}$} & \multicolumn{2}{|c|}{ Rooting (\%) } & \multicolumn{2}{|c|}{$\begin{array}{c}\text { Roots per } \\
\text { cutting (no.) }\end{array}$} & \multicolumn{2}{|c|}{$\begin{array}{l}\text { Total length } \\
\text { of roots }(\mathrm{cm})^{\mathrm{z}}\end{array}$} & \multicolumn{2}{|c|}{$\begin{array}{l}\text { Time to } 50 \% \\
\text { rooting }(\mathrm{d})\end{array}$} \\
\hline & $\begin{array}{c}\text { Single leaf } \\
\text { cuttings }\end{array}$ & $\begin{array}{l}\text { Terminal } \\
\text { cuttings }\end{array}$ & $\begin{array}{c}\text { Single leaf } \\
\text { cuttings }\end{array}$ & $\begin{array}{c}\text { Terminal } \\
\text { cuttings }\end{array}$ & $\begin{array}{l}\text { Single leaf } \\
\text { cuttings }\end{array}$ & $\begin{array}{l}\text { Terminal } \\
\text { cuttings }\end{array}$ & $\begin{array}{c}\text { Single leaf } \\
\text { cuttings }\end{array}$ & $\begin{array}{l}\text { Terminal } \\
\text { cuttings } \\
\end{array}$ \\
\hline Subirrigation medium (SM) & $48 \pm 4 \mathrm{~d}^{\mathrm{y}}$ & $27 \pm 4 d$ & $3.0 \pm 0.2 \mathrm{a}$ & $3.3 \pm 0.3 b$ & $8.3 \pm 0.6 b$ & $7.0 \pm 1.2 \mathrm{~b}$ & $一^{x}$ & - \\
\hline $22^{\circ} \mathrm{C}$ circulating water $\left(\mathrm{CW}_{22}\right)$ & $61 \pm 3 c$ & $52 \pm 3 c$ & $2.5 \pm 0.2 b$ & $3.0 \pm 0.3 \mathrm{~b}$ & $6.1 \pm 0.5 c$ & $6.4 \pm 0.7 b$ & $16 \pm 1 \mathrm{a}$ & $13 \pm 1 \mathrm{a}$ \\
\hline $26^{\circ} \mathrm{C}$ circulating water $\left(\mathrm{CW}_{26}\right)$ & $82 \pm 2 b$ & $62 \pm 3 b$ & $2.5 \pm 0.2 b$ & $3.0 \pm 0.2 \mathrm{~b}$ & $8.8 \pm 0.4 b$ & $7.8 \pm 0.6 \mathrm{~b}$ & $13 \pm 1 b$ & $8 \pm 1 b$ \\
\hline Cutting $(\mathrm{C})$ & \multicolumn{2}{|c|}{$35.52 * * w$} & \multicolumn{2}{|c|}{$3.37 \mathrm{NS}$} & \multicolumn{2}{|c|}{$35.52 * *$} & & \\
\hline Medium $(\mathrm{M})$ & \multicolumn{2}{|c|}{$8.28 *$} & \multicolumn{2}{|c|}{103.71 ** } & \multicolumn{2}{|c|}{$8.28 *$} & & \\
\hline $\mathrm{C} \times \mathrm{M}$ & \multicolumn{2}{|c|}{$0.34 \mathrm{NS}$} & \multicolumn{2}{|c|}{$12.65 * *$} & \multicolumn{2}{|c|}{$0.34 \mathrm{NS}$} & & \\
\hline
\end{tabular}

${ }^{\mathrm{z}}\left(1.8 \times{ }^{\circ} \mathrm{C}\right)+32={ }^{\circ} \mathrm{F} ; 1 \mathrm{~cm}=0.3937$ inch.

${ }^{y}$ Means with different letters with a column indicate significant differences $(P<0.05)$ by Duncan's multiple range test.

${ }^{x}$ Not measured.

${ }^{\mathrm{w}} \mathrm{F}$ values with indicated level of significance are given for each trait. Ns, ${ }^{*},{ }^{*}$ Nonsignificant or significant at $P<0.01$ or 0.001, respectively

provided more evidence that heating medium may help rooting percentage of softwood propagation. However, medium heating above $30{ }^{\circ} \mathrm{C}$ will decrease the rooting percentage for maple cuttings. This may be caused by the different plant species and overheating the perlite medium. Burholt and Van't Hof (1971) reported that root formation, which resulted from cell differentiation and elongation, is a temperature-regulated process with an optimum of $\approx 25{ }^{\circ} \mathrm{C}$ in sunflower (Helianthus annuus). Dykeman (1976) reported that optimal medium temperatures differed for root initiation and elongation, and these temperature optima also varied among species. Thus, in the application of the floating culture system, plant provenance and genotype should be considered when considering optimum water temperatures.

Applications of exogenous auxin also were effective in promoting adventitious root formation in grapes (Vitis spp.) (Keeley et al., 2003; Lu, 2005; Singh et al., 2004). We observed that the rooting percentage of SLC increased to $92 \%$ when we added $1.25 \mu \mathrm{M}$ NAA, but the rooting percentage at $2.5 \mu \mathrm{M}$ NAA medium was similar to the untreated control (Fig. 2). When we used $5 \mu \mathrm{M} \mathrm{NAA}$ medium, the rooting percentage decreased to $78 \%$. This result shows that a low concentration of auxin could increase the rooting percentage. NAA also appeared to shorten the adventitious root formation time of SLC. $R_{50}$ occurred around the sixth day for all NAA treatments, which was $6 \mathrm{~d}$ earlier than the untreated control (Fig. 2). TC in

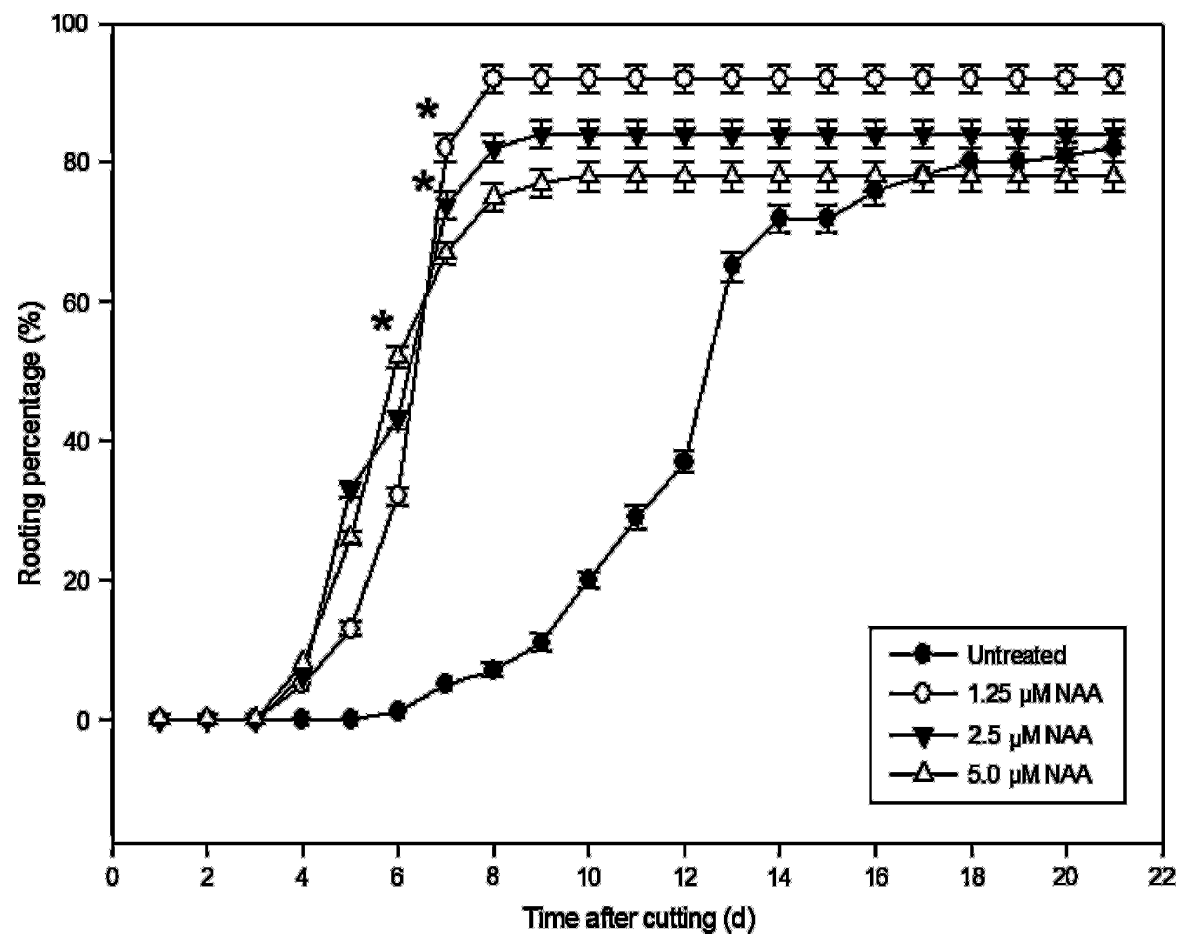

Fig. 2. Effects of 1-naphthalenacetic acid (NAA) solution concentration on rooting percentage of single leaf cuttings of taiwanese wild grape in the floating culture system. Distilled water was used as an untreated control. The temperature of solution was $26^{\circ} \mathrm{C}\left(78.8^{\circ} \mathrm{F}\right)$. The bars indicate SE. * Significant at $P<0.05$.

NAA solutions all wilted and rotted on the third to fifth day after treatments (data not shown). A similar phenomenon was reported in the vegetative propagation of eastern hemlock (Tsuga canadensis) softwood cuttings (Robert et al., 2005). The possible explanation is chemical toxicity.

This research demonstrates that the floating culture system could be used for clonal propagation of taiwanese wild grape in a controlled environment and that $30{ }^{\circ} \mathrm{C}$ circulating water is a sufficient medium. Softwood cuttings appear to be good starting materials for clonal propagation, especially for species that cannot form adventitious roots well by hardwood cuttings such as taiwanese wild grape.

\section{Literature cited}

Burholt, D.R. and J. Van't Hof. 1971. Quantitative thermal-induced changes in growth and cell population kinetics of Helianthus roots. Amer. J. Bot. 58:386393. 


\section{Research Reports}

Dykeman, B. 1976. Temperature relationship in root initiation and development of cuttings. Comb. Proc. Intl. Plant Prop. Soc. 26:201-207.

Goode, D.Z. and R.P. Lane. 1983. Rooting leafy muscadine grape cuttings. HortScience 18:944-946.

Keeley, K., J.E. Preece, and B.H. Taylor. 2003. Increased rooting of 'Norton' grape cuttings using auxins and gibberellin biosynthesis inhibitors. HortScience 38:281-283.

Komissarov, D.A. 1968. Biological basis for the propagation of woody plants by cutting. Israel Program for Scientific Translations. IPST, Jerusalem.

LeBude, A.V., B. Goldfarb, F.A. Blazich, W.C. Farrell, and J. Frampton. 2004. Mist, substrate water potential and cutting water potential influence rooting of stem cuttings of loblolly pine tree. Tree Physiol. 24:823-831.

Lu, M.C. 2005. Micropropagation of Vitis thunbergii Sieb. Et Zucc., a medic- inal herb, through high-frequency shoot tip culture. Scientia Hort. 107:64-69.

Mudge, K.W., V.N. Mwaja, F.M. Itulya, and J. Ochieng. 1995. Comparison of four moisture management systems for cutting propagation of bougainvillea, hibiscus and kei apple. J. Amer. Soc. Hort. Sci. 120:366-373.

Owen, J.S., Jr., W.A. Johnson, and B.K. Maynard. 2003. Effects of auxin concentration and medium temperature on four woody plant taxa propagated by stem cuttings using recirculating subirrigation in a growth chamber. J. Environ. Hort. 21:126-130.

Post, K. 1946. Automatic watering. New York State Flower Growers Bul. 7:3-14.

Robert, M.J., J. Frampton, and F.P. Hain. 2005. Vegetative propagation of mature eastern and carolina hemlocks by rooted softwood cuttings. HortScience 40: 1469-1473.

Sabir, A., Z. Kara, F. Kucukbasmact, and N.K. Yucel. 2004. Effects of different rooting media and auxin treatments on the rooting ability of Rupestris du Lot (Vitis rupestris) rootstock cuttings. J. Food Agr. Environ. 2:307-309.

Singh, S.K., R.N. Khawale, and S.P. Singh. 2004. Technique for rapid in vitro multiplication of Vitis vinifera L. cultivars. J. Hort. Sci. Biotechnol. 79:267272.

Soffer, H. and D.W. Burger. 1988. Effects of dissolved oxygen concentrations in aero-hydroponics on the formation and growth of adventitious roots. J. Amer. Soc. Hort. Sci. 113:218-221.

Zhang, H., W.R. Graves, and A.M. Townsend. 1997. Water loss and survival of stem cuttings of two maple cultivars held in subirrigated medium at 24 to $33^{\circ} \mathrm{C}$. HortScience 32:129-131.

Zimmerman, P.W. 1930. Oxygen requirements for root growth of cuttings in water. Amer. J. Bot. 17:842-861. 